\title{
The Impact of Key Success Factors Implementation on Profit Performance Within Malian Small Size Industry SODEMA
}

\author{
Tiédian Fané ${ }^{1} \&$ Toumani Bagayoko ${ }^{1}$ \\ ${ }^{1}$ Faculté des Sciences Economiques et Gestion, Université des Sciences Sociales et de Gestion, Bamako, Mali \\ Correspondence: Tiédian Fané, Faculté des Sciences Economiques et Gestion, Université des Sciences Sociales et \\ de Gestion, Bamako, Mali. E-mail: fseggroupe@gmail.com
}

Received: July 1, 2019

Accepted: July 28, 2019

Online Published: August 7, 2019

doi:10.20849/abr.v4i2.619

URL: https://doi.org/10.20849/abr.v4i2.619

\begin{abstract}
This study highlights the impact of key success factor on profit performance. The recommendations should be used as guideline for Malian enterprises.

The quantitative and qualitative methods, primary data collected by questionnaires and interviews are used. Secondary data are gotten from articles, journals and online resources. The research framework was analyzed using multiple regression models. Hypothesis test is adopted to accept or reject the hypothesis formulated in this research. Excel software have been used to perform the test, the measures of p-value, coefficient of determination, the adjusted coefficient of determination, the degree of freedom, the coefficient of Fisher and its critical value.

The results suggest that key success factors have significant impact on profit performance. Key success factors have a positive impact on profit performance is valid hypothesis. This study makes several contributions to research and theory of key success factors and profit performance. A greater understanding of key success factors and profit performance provided further investigation of the relationship between of key success factors and profit performance. This model can be used by other enterprise to increase its profit performance. Through the use of this model, enterprise can quickly identify areas requiring urgent improvement.
\end{abstract}

SODEMA industry needs improvement in chain communication systems, manufacturing techniques, and transportation capabilities as alternatives to investing in large inventories and production capacities. The theoretical model developed in this study is applicable in practice.

Keywords: key success factors, profit performance, competitive advantage, Multiple Regression

\section{Introduction}

Globalization, deregulation and trade liberalization have increased the vulnerability of national economies to international competition. Mali has several competitive problems. Mali is liberalizing its economy. Malian manufactured goods must compete with products of other countries with fully developed industrial economies. The competitive advantage is not driven exclusively by proper marketing, good investments, employee skills, but also by using traditional key factors such us high level of quality, lower prices, lower production costs and shorter delivery times. Reduced transportation costs, shorter in-transit times, and value-added services can be major factors in improving the competitive position of the supply chain. The key success factor is a polysemous term: in microfinance it's the ability to innovate, in the luxury industry it is brand image, the key factors of success can evolve over time. In general, the lower your production cost, the higher your profit. Profit is the amount that your business ultimately earns, after subtracting expenses, such as operating costs from gross revenue. An increase in costs will decrease profits; this could include labor costs, raw material costs and cost of rent. As competitive we can call the firm which can produce services or products of superior quality and lower costs than its domestic and international competitors. Finally, the implementation of key success factors and profit performance within Malian enterprises is not an option but an imperative.

Is the use of key factors of success an effective way to boost the competitiveness of Malian enterprises?

The overall objective of this study is to provide sufficient guidelines to help Malian enterprises in the implementation of key success factors and profit performance. This study is focused on the current impact of key 
success factors implementation on profit performance within Malian firm SODEMA. It has following specific objectives:

1. To obtain the effects of key success factors implementation on profit performance in Malian firm SODEMA;

2. To obtain a key success factors implementation model for Malian firms;

3. To specify and test hypotheses from the research model of key success factors and profit performance which is derived from their theoretical foundations,

4. To obtain success factors knowledge with specific characteristics of Malian firms generated new knowledge.

Based on the literature review, informal discussions with management practitioners, and research objectives, the research questions were proposed. They are listed as follows:

Question1: What are quality, production cost, price and delivery time? Question2: What is profit? Question3: Are key success factors effective way for getting profit performance? Question4: What kind of theoretical model for implementing key success factors should be developed to guide Malian companies in implementing key factors of success? Question5: What is the extent of the relationship between key success factors and profit performance? Question6: How can this model of key success factors implementation be demonstrated in practice?

\section{Literature Review}

The first, second and third research questions - "What are Quality, production Cost, price and delivery time?; What is profit ? Are key success factors effective way for getting profit performance?" are descriptive in nature. When reviewing the relevant literature on key success factors, it was found that different researchers had different definitions of Quality, and frameworks based on their own understandings of Quality and research objectives. A wide variety of approaches to defining quality are evident: Quality is defined as being about value (Feigenbaum, 1983), the fitness for use (Juran, 1989), the excellence (Peters and Waterman, 1982). "Quality refers to the amounts of the unpriced attributes contained in each unit of the priced attribute." (K.B Leffler, 1982) Quality means best for certain customer conditions, these conditions are (a) the actual use (b) the selling price of the product." (A.V Feigenbaun, 1983) Quality is the degree to which a specific product satisfies the wants of a specific consumer." (H.L Gilmore, 1974) Product Quality is defined as the collection of features and characteristics of a product that contribute to its ability to meet given requirements and service quality is the gap between what the customers want and what they actually get or perceive they are getting (Berry et al., 1988).

During the past few decades service quality has become a major area of attention to practitioners, managers and researchers owing to its strong impact on business performance, and profitability. One of the most critical challenges that US firms faced in the 1980s was to provide consistently high quality goods and services (Leonard and Sasser 1982; Zeithaml, Berry, and Parasuraman 1986). Quality-management gurus have alwas assumed that maintaining product quality would improuve profitability (RC McNally, MB Akdeniz, RJ Calantone, 2011). Quality is even more critical in supply chains using just-in-time manufacturing and low inventory levels because there are fewer buffers to protect against quality failures (National Research Council.2000).There is a growing body of evidence indicating that providing high quality goods and services enhances profitability, improves productivity, increases market share and return on investment, and reduces costs (Chang, and Buzzell, 1983).

In recent years, companies have reduced their dependency on traditional accounting systems by developing activity-based cost management systems. Initially, managers viewed the $\mathrm{ABC}$ approach as a more accurate way of calculating product costs. But $\mathrm{ABC}$ has emerged as a tremendously useful guide to management action that can translate directly into higher profits (R Cooper, RS Kaplan - Harvard business review, 1991). Production costs are expenses, such as materials and labor, that your company incurs in the course of producing the product that you sell to consumers, firms can be distinguished with respect to their level of cost- or production efficiency (Demsetz, Demsetz H. 1973). According to Drury (2004), Cost efficiency focuses on cost reduction and continuous improvement and change rather than cost containment. The idea of cost reduction of a production unit was first introduced by Farell (1957), under the concept of "input oriented measure". Farrell, J. (1957) Opportunities for internal cost reductions include direct labor, materials, scrap, and rework. Other opportunities can be found through creative reductions in overhead (National Research Council, 2000). 
- The price is the exchange value a product or service in the marketplace (Geoffrey York 1989). Pricing goals include profitability objectives (profit maximization) and volume objectives (profit maximization) (Costa Nicola 1989). Effectiveness of the sales advertisement depends concurrently on the amount of price reduction (SJ Tan, S Hwang Chua, 2004). Price increase causes fewer sales of factory-made cigarettes and higher sales of cheaper loose tobacco in Germany (R Hanewinkel, C Radden, T Rosenkranz, 2008).

Silver et al. defined, delivery time as the time that elapses between the placement of an order and the receipt of the order into inventory, delivery time may influence customer service and impact inventory costs.

Achieving superior delivery performance is the primary objective of any industry supply chain. As the number of resources, operations and organizations in supply chain increases, variability destroys synchronization among the individual processes, leading to poor delivery performance (Garg et al., 2004. Garg, D., Narahari, Y., \& Viswanadham, N. 2003). On-time delivery (OTD) is therefore a major concern of the manufacturing as well as the distribution functions (C. Madhusudhana Rao, 2011).

\section{Theoretical Model}

Research Question 4: "What kind of theoretical model for implementing keys factors of success should be developed to guide Malian enterprises. This model is based on the assumptions that the key success factors constructs have positive effects on profit performance. Key success factors constructs are: high level of quality, lower prices, lower production costs, shorter delivery times. These assumptions must be confirmed by questionnaire survey data in the Malian company SODEMA. Based on these assumptions, a theoretical model for implementing key success factors and profit performance has been developed. In this study, the key success factors implementation constructs are the independent variables (causes) and profit performance is the dependent variable (effect). The following hypotheses have also been proposed:

H1: high level of quality has a positive impact on profit performance.

$\mathrm{H} 2$ : lower prices has a positive impact on profit performance.

$\mathrm{H} 3$ lower production costs has a positive impact on profit performance.

H4: shorter delivery times has a positive impact on profit performance.

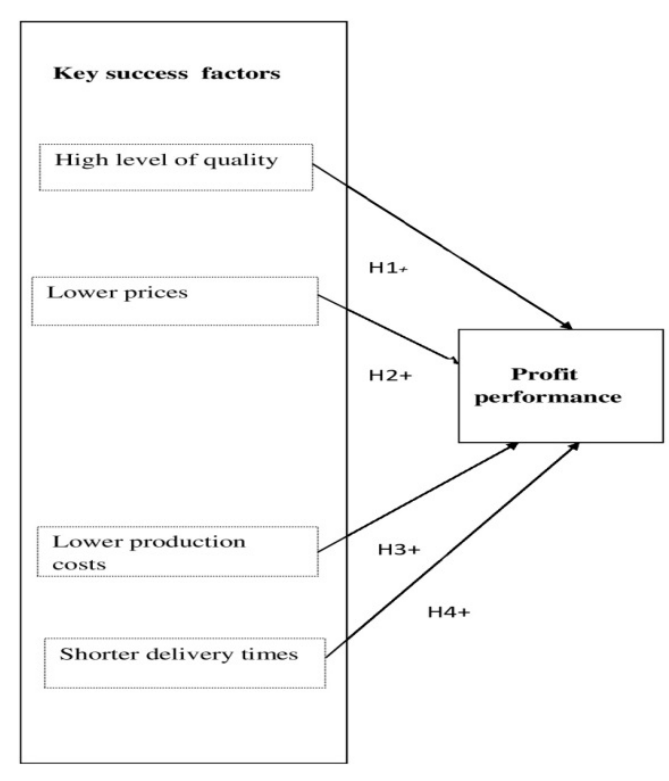

Figure 1. Key success factors and profit performance 


\section{Methodology of Case Study}

The sixth research question is "How can this model of key success factor implementation are demonstrated in practice?" The Malian company SODEMA puts this model of key success factor into practice and can also provide a better understanding of the model.

\subsection{A Brief Introduction of SODEMA}

The case study was conducted in a SODEMA small-size industry. It is located in the zone industrielle of Bamako in Mali. It produces soap and several products which can be used in the cosmetic industry. The company has a functional organizational structure.

\subsection{Data Collection}

Primary and secondary data sources are used.

\subsubsection{Primary Data Sources}

\section{a) Interviews and observations}

Interviews were conducted with customers, suppliers, quality managers, marketers, production managers, inspectors and operators as well as observations.

\section{b) Questionnaire survey}

\section{- key success factor Survey}

The research question "What is the extent of the relationship between key success factor and profit performance?" has been answered. Key success constructs are used for following statements: "Dear customers, could you please take a minute to tell us how satisfied are you with the quality of goods and services provided by SODEMA? "HQP", "Dear production managers how satisfied are you with the production costs of goods and services provided by SODEMA? "LPC", Dear customers how satisfied are you with the price level of goods and services provided by SODEMA? "LP", Dear suppliers how satisfied are you with the delivery times of goods and service offer by SODEMA? "SDT". We will use those information to help us to improve our ability to deliver projects in the future. Respondents to these items were used five-point Likert format for 10 months from January2018 to October 2018 ranging from 1 to 5 as follows: 1 to 2 Very dissatisfied, 2 to 3 dissatisfied, 3 to 4 satisfied, 4 to 5 Very satisfied.

\section{- Profit performance Survey (dependent variable)}

The organization has to evaluate its profit performance. The rating scale is as follows: 1 to 2 Very dissatisfied, 2 to 3 Dissatisfied, 3 to 4 Satisfied, 4 to 5 Very satisfied.

\subsubsection{Secondary Data Sources}

Textbooks, academic articles and journals related to the implementation of key success factors have been used. A number of online resources have been used to obtain information for the literature review.

\subsection{Case Study Questions}

Only one company, SODEMA has been selected to lead this case study.

Three questions are addressed in this study, which are listed as follows:

Question 1: What are the strengths of the current implementation of key success factors and profit performance?

This is a descriptive question on the strengths of the key success factors and profit performance approach compared to the key success factors Model. After the comparison, the strengths of the implementation of the key success factors and profit performance of the company could be identified.

\section{Question 2: What are the weaknesses of the key success factors and profit performance of the company?}

Current Practices of key success factors and profit performance were compared to the Total key success factors Implementation Model. Thus, weak areas could be identified. Weaknesses could be used by the company as opportunities to seek improvement actions and develop an improvement plan.

Question 3: What type of improvement can the company implement in its entirety?

\subsection{Data Analysis}

The research framework of this study was analyzed using multiple regression models. Hypothesis tests have been adopted to accept or reject the hypotheses formulated in this research. Excel software have been used to 
perform the tests, the p-value analysis for individual coefficients, and the F-test for the overall importance of the model.

Data are collected for 10 months from January2018 to October 2018.

Table 1. Data for Excel input on the key success factors and profit performance

\begin{tabular}{lllll}
\hline $\mathbf{Y}$ & $\mathbf{X} 1$ & $\mathbf{X} 2$ & $\mathbf{X 3}$ & X4 \\
\hline $\mathbf{P P}$ & $\mathbf{H L Q}$ & $\mathbf{L P}$ & $\mathbf{L P C}$ & SDT \\
\hline 5 & 4 & 4 & 4 & 4 \\
\hline 4 & 3 & 3 & 3 & 3 \\
\hline 5 & 4 & 2 & 2 & 2 \\
\hline 3 & 2 & 3 & 3 & 4 \\
\hline 3 & 2 & 3 & 2 & 3 \\
\hline 2 & 2 & 5 & 5 & 5 \\
\hline 4 & 3 & 4 & 4 & 3 \\
\hline 3 & 3 & 2 & 2 & 3 \\
\hline 5 & 4 & 1 & 2 & 4 \\
\hline 4 & 3 & 3 & 4 & \\
\hline
\end{tabular}

\section{Results}

The results of the regression analysis suggest that the practice of key success factors has a significantly positive relationship with Profit performance.

Table 2. Multiple Regression Results

\begin{tabular}{llllll}
\hline 0 & 1 & 2 & 3 & 4 & \\
\hline & 0 & 1 & 2 & 3 & SDT \\
\hline $\boldsymbol{b}$ & Intercept & HLQ & LP & LPC & $-0,3$ \\
\hline $\boldsymbol{s}(\boldsymbol{b})$ & 1,27778 & 1,02222 & 0,0222 & 0,1222 & 0,4169 \\
\hline $\boldsymbol{t}$ & 1,57625 & 0,32061 & 0,3583 & 0,4355 & $-0,7197$ \\
\hline $\boldsymbol{p}$ & 0,81064 & 3,18838 & 0,062 & 0,2806 & 0,5040 \\
\hline
\end{tabular}

\subsection{Multiple Regression Equation}

Profit performance PP = b0 + b1 (HLQ) + b2 (LP) + b3 (LPC) + b4 (SDT).

Estimation of a multiple linear regression equation

- Excel will be used to generate coefficients and measures of quality of fit for multiple regression

- Excel: Tools / Data Analysis ... / Regression

$\mathbf{P P}=1,27778+1,02222(\mathbf{H L Q})+0,0222(\mathbf{L P})+0,1222$ (LPC) $-0,3$ (SDT)

Table 3. ANOVA table

\begin{tabular}{|c|c|c|c|c|c|c|}
\hline Source & SS & $\mathrm{df}$ & MS & $\mathrm{F}$ & F-Crit & $p$-Value \\
\hline Regn. & 8,32222 & 4 & 2,0806 & 8,1413 & 5,1922 & 0,0205 \\
\hline Error & 1,27778 & 5 & 0,2556 & $\mathrm{R}^{2}$ & & \\
\hline Total & 9,6 & 9 & 1,0667 & 0,8669 & 0,7604 & \\
\hline
\end{tabular}




\section{- Coefficient of determination: $\mathrm{R}^{2}$}

The coefficient of determination reports the proportion of total variation in $\mathrm{y}$ explained by all $\mathrm{x}$ variables taken together.

This is the ratio of the explained variability to total sample variability.

$\mathrm{R}^{2}=0,8669$ means $86,69 \%$ of the variation in Profit Performance is explained by the variation in key success factor implementation constructs.

\section{- Adjusted $\overline{R^{2}}$}

This is the ratio of the explained variability to total sample variability taking into account the sample size and number of independent variables.

Adjusted $\overline{R^{2}}=0,7604$

\subsection{Hypotheses Testing}

Accept or reject your hypothesis

\subsubsection{Test Associated With the Overall Evaluation of the Model: Fischer Test (F-Test)}

a) Some formulations of the global "significance" test: • Is the model relevant to explaining the values of $Y$ ? Is the linear connection $\mathrm{Y} / \mathrm{x} 1, \mathrm{X} 2, \mathrm{X} 3$ lawful? $\bullet$ Hypothesis test It is a matter of accepting or rejecting a hypothesis, $\mathrm{H} 0$ is the null hypothesis and $\mathrm{H} 1$ is the alternative hypothesis. Hypotheses: $\mathrm{H} 0: \beta \mathrm{j}=0$ (absence of linear relation) $\mathrm{H} 1: \beta \mathbf{j} \neq 0$ (existence of linear relation between $\mathrm{xj}$ and $\mathrm{y}$ ).

\section{b) statistical tests}

- At a given statistical level 5\%, compare the F-calculated with the F-theoretical provided by the table.

- Compare the P-value with the level of significance the

P-value is the probability that any event is the mere act of chance. Arbitrarily, it is generally considered that "statistically significant" values of p less than one chance in twenty (20), ie the probability that a value is due to chance does not exceed 5\%. A P value less than 0.05 is statistically significant otherwise it is not. We speak of a highly significant value if p-value is less than a chance in a hundred (100) or p-value less than 0.01 .

\subsubsection{Individual Evaluation of the Coefficients: Student Test}

\section{a. Statistical tests}

Does a variable contribute significantly to the model? At a given level of meaning $5 \%$ it is a matter of comparing $\mathrm{t}$-calculated with t-theoretical provided by the student table or comparing the p-value with the level of significance. A p-value less than 0.05 , is significant and less than 0.01 is highly significant. On the other hand, a $\mathrm{p}$-value greater than 0,05 is not significant.

\subsubsection{Associated Hypothesis Test}

$\mathrm{H} 0$; aj $=0$, H0 is verified means that the variable can be removed from the model without damaging the explanatory power.

\section{Discussion}

\subsection{Interpretation of the Linear Multiple Regression Equation}

PP will increase, on average, 1,02222 per month for each increase to 1point HLQ score, net of the effects of changes due to the other key success factor implementation constructs.

PP will increase, on average, by 0,0222 per month for each increase to 1point LP score, net of the effects of changes due to the other key success factor implementation constructs.

PP will increase, on average, by 0,1222 per month for each increase to 1point LPC score, net of the effects of changes due to the other key success factor implementation constructs.

PP will decrease, on average, by 0,3 per month for each increase to 1point SDT score, net of the effects of changes due to the other key success factor implementation constructs. 


\subsection{Interpretation of Individual Evaluation of the Coefficients}

The results of the regression analysis for individual significance of the model implied that:

- For X1, High level of quality, p-value $=0,0243$, this value being less than 0.05 , is significant (Table 2);

- For X2, lower production costs, $\mathrm{p}$-value $=0,9529, \mathrm{P}$-value more than 0.05 , is not significant (Table 2);

- For X3, lower price, $\mathrm{p}$-value $=0,7902$, P-value more than 0.05 , is not significant (Table 2);

- ForX4, p-value $=0,5040, \mathrm{P}$-value more than 0.05 , is not significant (Table 2);

Lower production costs, lower price and shorter delivery time have no significant relationship with profit performance ( $\mathrm{p}$-value more than 0,05 for each variable).

Conclusion: $\mathrm{H} 1, \mathrm{H} 2, \mathrm{H} 3$ and $\mathrm{H} 4$ are valid hypotheses.

\subsection{Interpretation of Overall Evaluation of the Coefficients}

$\mathrm{F}=8,1413$ and its critical value is 5,1922 with a degree of freedom equal to 4 . Its P-value being equal to 0,0205 . $\mathrm{P}$ - value is statistically significant because it is less than 0.05 (Table 3 ).

Conclusion: $\mathrm{H} 1, \mathrm{H} 2, \mathrm{H} 2, \mathrm{H} 3, \mathrm{H} 4$ (which offer a positive relationship between key success factors and profit performance) are valid.

\subsection{Interpretation of the Coefficients of Determination}

$\mathrm{R}^{2}=0,8669$ means $86,69 \%$ of the variation in Profit Performance is explained by the variation in key success factor implementation constructs.

Adjusted $\overline{R^{2}}=0,7604$ means $76,04 \%$ of the variation in profit performance is explained by the variation in key success factors implementation constructs, taking into account the sample size and number of independent variables.

\subsection{Justification of the Approach}

Primary data are information collected directly by the researcher, when secondary data are not available or are unable to contribute to the achievement of research objectives (Sekaran, 2003).

According to Yin (1989), case studies are the preferred strategy when "how" or "why" are questions asked. Regression analysis is used to understand which among the independent variables are related to the dependent variable, and to explore the forms of these relationships. In restricted circumstances, regression analysis can be used to infer causal relationships between the independent and dependent variables.

\section{Recommendations/Suggestions}

These potential opportunities for improvement borrowed from American National Research Council. 2000 are listed as follows:

- Techniques, such as just-in-time manufacturing, activity-based costing (ABC), vendor-managed inventory, and lean manufacturing, can be used effectively to reduce non-value-added costs;

- In response to increasing demands for rapid delivery and customized products, small and medium-sized manufacturing enterprises should consider using advanced supply chain communication systems, flexible manufacturing techniques, and modern transportation capabilities as alternatives to investing in large inventories and production capacities;

- In response to the requirements of integrated supply chains for improved quality, small and medium-sized manufacturing enterprises should adopt quality as a competitive strategy and consider implementing techniques, such as six sigma, ISO certification, and statistical process controls, to comply with customer demands, improve overall business performance, and provide a common language for communication on quality issues.

\section{Contributions / Limitation and Future Research Perspectives}

This study contributes to enriching research and theory on success factors and profit performance. A good understanding of success factors and profit performance derived from the relationship between success factors and profit performance was facilitated. As a limitation, the case study was run in one company. Strictly speaking, the generalization of its conclusions is limited. Enterprises have different characteristics, different stories, different technologies, different maturity of success factors and profit performance and employ people with different levels of education ... Different enterprises have to use different approaches to success factors and profit 
performance. There is no universal standard for implementing this model. In prospect of a new research the case study will be directed in different types of enterprises. It will be more interesting to include in the model moderating and mediating variables.

\section{Conclusion}

In conclusion, the main purpose of this research study was to investigate the relationships between key success factors and profit performance as perceived by customers in Malian small size industry SODEMA.

A number of conclusions have been obtained from this research. Thus, a key success factors theoretical model related to Malian firms has been developed.

First, the instruments for measuring key success factors and profit performance are reliable and valid, and can be used by other researchers to test the effects of key success factors on profit performance.

Second, several conclusions have been obtained from testing the theoretical model:

(1) High level of quality has a positive impact on profit performance, (2) lower prices has a positive impact on profit performance, (3) lower production costs has a positive impact on profit performance, (4) shorter delivery times has a positive impact on profit performance.

Third the key success factors implementation model developed in this study is applicable in practice. This model can be used by Malian firms to improve their key success factors implementation efforts. This key success factors implementation model can be used to self-assess firms' profit improvement efforts and measure their progress over time.

Through using this model, firms can quickly identify which areas urgently need improvement. Thus, the resources can be allocated more wisely and more effective improvement plans can be formulated.

Based on the evaluation, the strengths and weaknesses of the firm's key success factors implementation and profit performance were identified. The firm's current key success factors implementation practices showed that it did not implement the full package of the key success factors implementation model.

The weaknesses of the firm's key success factors implementation and profit performance provided opportunities for the firm to improve its key success factors implementation. Based on these weaknesses, the firm's targeted improvement area of profit performance, and the firm's available resources, an improvement plan was formulated. The firm's deputy general manager agreed that the firm would implement this improvement plan in practice.

Thus, it can be concluded that this key success factors implementation model can be used to evaluate the firm's key success factors implementation, profit performance and customer orientation, identify strengths and weaknesses therein, and assist the firm in formulating the improvement plan. Therefore, the key success factors implementation model developed in this study is applicable to this firm.

Can this key success factors implementation model be used in other Malian firms? In fact, the case study was conducted in only one firm. Strictly speaking, the generalization is limited. Firms' weak areas of key success factors and profit performance can always be identified by comparison with this key success factors implementation model. Weak areas can be used by firms to further improve their key success factors implementation.

Thus, the conclusion obtained from the case study can be generalized to other firms in Mali. Therefore, the key success factors implementation model developed in this study is applicable to all Malian firms. Through using this model, firms can quickly identify which areas urgently need improvement. Thus, resources can be allocated more wisely. In fact, key success factors implementation is a systematic approach. Different firms have different characteristics, histories, and backgrounds; adopt different technologies; have different key success factors implementation maturity; serve different markets with different products; and employ people from different education levels. Different firms should adopt different approaches to key success factors implementation on the basis of their own situations. No universal standard of key success factors implementation exists. Firms should not follow the practices presented in this key success factors implementation model strictly; when they start using it, they should combine their uniqueness with the practices of this model and consequently develop their own models and ways to excellence. Through this, their own models can suit their situations better. Their own measurement systems can better fit their situations. It should be noted that top management commitment is the most important prerequisite; without it, it is impossible to successfully implement this model in practice.

Implementing this model does require patience, tenacity, and commitment from people at every level in firms. It will take some time to see the effects of implementing this model. 


\section{References}

Berry, et al.. (1988, January). A multiple- Item Scale for measuring consumer perceptions of service quality. Journal of Retailing.

Chang, \& Buzzell. (1983). Product Quality, Cost Position, and Business Performance: A Test of Some Key Hypotheses. Journal of Marketing, 47(2), 26-43. https://doi.org/10.1177/002224298304700204

Costas, N. (1989, January 29). How to cut high price to Gasoline. The Winnipeg Free Press, p.7.

Demsetz, H. (1973). Industry Structure, Market Rivalry, and Public Policy. Journal of Law and Economics, 16(1), 1-9. https://doi.org/10.1086/466752

Drury. (2004). Management Cost Accounting Students Manual, May 20.

Farell. (1957). Under the concept of "input oriented measure".

Farrell, J. (1957). The Measurement of Productive Efficiency. Journal of Royal Statistical. https://doi.org/10.2307/2343100

Feigenbaum, A.V. (1983). Total Quality Control (3rd ed.), p.1. McGraw-Hill, New York.

Garg, D., Narahari, Y., \& Viswanadham, N. (2003). A New Approach to Achieving Sharp and Timely Deliveries in Supply Chain Networks. Proceedings of the IEEE International Conference on Intelligent Robots and Systems, October, 2315-2320. https://doi.org/10.1109/IROS.2003.1249216

Geffrey, Y. (1989). Coke Fined 65,000 dollars for Winnipeg price fixing. The Globe and Mail, January 14, p.85.

Gilmore, H.L. (1974, June). Product conformance cost. Quality Progress, 74.

Hanewinkel, R., Radden, C., \& Rosenkranz, T. (2008). Health Economics. Wiley Online Library.

Juran, J.M. (1989). Juran on Leadership for Quality. The Free Press, New York.

Leffler, K.B. (1982, December). Ambiguous changes in product quality. American Economic Review, 956.

McNally, R.C., Akdeniz, M.B., \& Calantone, R.J. (2011). Product innovativeness dimensions. Journal of Product Innovation Management, 28(s1), 63-77. https://doi.org/10.1111/j.1540-5885.2011.00861.x

National Research Council. (2000). Surviving Supply Chain Integration: Strategies for Small Manufacturers. Washington, DC: The National Academies Press. https://doi.org/10.17226/6369

Peters, T.J., \& Waterman, R.H. (1982). In Search of Excellence: Lessons from America's Best-Run Companies. Harper \& Row, New York.

Rao, C. M. (2011). C. Madhusudhana rao delivery performance measurement in an integrated supply chain management: case study in batteries manufacturing firm. Serbian Journal of Management 6(2), 205-220. https://doi.org/10.5937/sjm1102205M

Sekaran, U. (2003, November 9). Research Methods for Business: A Skill-Building Approach. Open Access Library Journal, 3(11), 2016.

Silver, E.A., Pyke, D.F., \& Peterson, R. (1998). Inventory Management and Production Planning and Scheduling. New York. Wiley.

Tan, S.J., \& Chua, S.H. (2004). “While stocks last!” Impact of framing on consumers' perception of sales promotions. Journal of Consumer Marketing, 21(5), 343-355. https://doi.org/10.1108/07363760410549168

Yin, R.K. (1989). Case Study Research, Design and Methods (Revised ed.). Sage Publications, London.

\section{Copyrights}

Copyright for this article is retained by the author(s), with first publication rights granted to the journal.

This is an open-access article distributed under the terms and conditions of the Creative Commons Attribution license (http://creativecommons.org/licenses/by/4.0/). 